\title{
Aoristo)))))
}

International Journal of Phenomenology, Hermeneutics and Metaphysics

\section{For a metaphysics out of joint: Deleuze, Heidegger: Pathways between metaphysics and transcendental philosophy}

\author{
Per una metafisica fuori dal comune: Deleuze, Heidegger: \\ Percorsi tra metafisica e filosofía trascendentale
}

Prof. Dr. Maurizio Candiotto

Università degli Studi di Písa.'

\begin{abstract}
In Heidegger the ontological difference is one between any intra-worldly entities and the very horizon of their appearing, the world itself. Both E. Fink and J.-P. Sartre elaborated on this, and so further did Deleuze; even his and Guattari's Anti-Oedipus draws ultimately on the utterly Heideggerian idea of an ontological difference as one between world and worldly entities. Now the very architecture of traditional (Wolffian) special metaphysics - although programmatically entityoriented - gets thereby affected, namely in its first part, rational psychology. From Heidegger through Fink and Sartre until Deleuze, the move of opening the metaphysical dimension of thought to the transcendental one in order to do justice to the ontological difference goes along with that of blowing psychology up (and indeed psyche itself) within the very domain of metaphysics.
\end{abstract}

\section{KEYWORDS}

Metaphysics; transcendental philosophy; metaphysics out of joint; Heidegger; Deleuze

\section{ABSTRACT}

In Heidegger la differenza ontologica intercorre fra ogni ente intramondano e il mondo stesso,

${ }^{1}$ Email: mauriziocandiotto@hotmail.com. Orcid: https://orcid.org/0000-0003-4861-3247

Maurizio Candiotto Toledo, n'5,v. 1 (2020) p. 179-187 
International Journal of Phenomenology, Hermeneutics and Metaphysics

orizzonte d'apparire degli enti tutti. Sia E. Fink che J.-P. Sartre hanno rielaborato questa idea fondamentale, e dopo di loro G. Deleuze; anche l'Antiedipo, scritto con F. Guattari, attinge in ultimo all'idea, di chiara marca heideggerina, di una differenza tra il mondo e gli enti mondani. Ciò si ripercuote sull'architettura stessa della metafisica, fino ad agire sulla metafisica speciale che pure è dedicata, nella sua partizione tradizionale (wolffiana), ad articolare l'ente; in particolare, sulla prima parte di questa, la psicologia razionale. Da Heidegger a Fink e Sartre fino a Deleuze, la mossa di aprire la dimensione metafisica del pensiero a quella trascendentale per rendere giustizia alla differenza ontologica è strettamente intrecciata a quella di far esplodere, all'interno della metafisica stessa, la psicologia e fin l'idea di qualcosa come una psiche.

\title{
KEYWORDS
}

Metafisica; filosofia trascendentale; metafisica fuori dal comune; Heidegger; Deleuze

\section{INTRODUCTION}

\author{
The circle is not round \\ (Milčo Mančevski, Before the Rain)
}

The world as a horizon surrounding each single intra-worldly being: this intuition is one of the roots of Heidegger's investigation of the Being in its difference from entity ${ }^{2}$. The tie between world and Being is so tight that the ontological difference is one between the intra-worldly (entity) and the world itself, as the horizon of its appearing. In Being and Time this paves the way to the Destruktion of Western metaphysics, namely inasmuch as it takes up the figure of psychology. As we shall see, the latter is both a section of special metaphysics according to Wolff's architecture and, at the same time, a way of conceiving of being and truth that is pivotal for the very project of metaphysics as such. ${ }^{3}$

The analytic of Existence, where the world is the horizon of appearing in the way of an enchaining forwarding from entity to entity, constitutes an alternative to the 'mentalist' manner of understanding the appearing of things within the world. The latter approach, on the contrary, is entirely intra-worldly: to appear is to appear to a mind, which is in turn an entity, a piece of the world4. By this very fact, such a mentalist approach is unable to grasp Being itself, the appearing, as such, of the

\footnotetext{
${ }^{2}$ Such an intuition owes much to Husserl's and has, further, a background stemming from the $19^{\text {th }}$ Century philosophy of logic: in facts, Frege and even Bolzano are Husserl's forerunners - quite unexpectedly, in this respect; and therefore also Heidegger's - even more unexpectedly. On this, I take the liberty to mention here my paper "Représentations sans relation. Bolzano et Frege" Esercizi filosofici 7/2012, p. 20-32).

${ }^{3}$ See Heidegger [1950], [1967]; interesting remarks are found in Sini [1985] and [1989].

${ }^{4}$ It would be interesting to compare the anti-mentalism displayed in Time and Being with the one elaborated by Gilbert Ryle; in facts, his Concept of Mind owes to Heidegger's book, which Ryle had introduced to the English readers 20 years earlier with a review.
}

For a metaphysics out of joint: Deleuze, Heidegger... 


\section{Aoristo)))))}

International Journal of Phenomenology, Hermeneutics and Metaphysics

entity; which is, in turn, the appearing of the entity as such, i.e. as an entity, inasmuch as it is given, and is to be understood, in its being. To grasp that, however, is to grasp the 'liminal' insistence of the world, its implicit but irreducible co-presence at each item within it.

From Heidegger two lines of thought stem that are quite independent from, but also respond to each other by resonance. Thanks to their interaction in the distance, we shall be allowed to get back to reconsider the architecture of metaphysica specialis. Admittedly, that architecture will turn out quite shaken and so impacted on to get blurred; and though it is worth the effort to recognize it - weren't in order to appreciate the effects of its Destruktion.

The first line is at work in Das Spiel as Weltsymbol by Eugen Fink. On the other hand, the approach to the world taken by Deleuze and Guattari in the Anti-Oedipus can also be traced back to Heidegger through the first reception of Sein und Zeit in France, namely by Sartre. Now, while the first of these lines takes step directly and explicitly from Heidegger, the other does not; this, however, does not prevent them to resound, nor their resonance to be fruitful. Moreover, in both cases a factual - not merely de jure - link with Heidegger can be established (although partly mediated by Sartre, in the second case).

\section{SPECIAL METAPHYSICS AND TRANSCENDENTAL PHILOSOPHY}

Within special metaphysics, it is the relationship between cosmology and psychology that is exposed, in the first place, to the Destruktion of metaphysics as such. Let's begin with the French side of it. The two main theses of Anti-Oedipus can be so resumed: desire is productive rather than representative; it is the world that explains the psyche, not vice versa. The two theses are in fact intertwined: desire, precisely because it is productive, always performs in a cosmic network ${ }^{5}$. Inasmuch as it is productive, desire is world: it is a strain of the world running along its entire span, rather than a psychic entity with its mental representations (maman et papa, of course). As we shall see, while this anti-mentalism does integrate in itself the results of Deleuze's previous work on Nietzsche and Bergson, it also inherits Heidegger's (and Husserl's) primacy of the world (pure consciousness, respectively) on any intraworldly item, including mind. The (by no means missing) link between Deleuze and Heidegger is to be found in Sartre's early writings ([1935], [1939]). Chez Sartre, the talk of the world matches strictly the one of transcendental consciousness: the latter is transcendental just because it is open to the world - to nothing less than the world,

\footnotetext{
${ }^{5}$ The world here named is of course rather the "chaosmos" sketched by Deleuze rather than the kosmos spelled out by cosmology in the traditional special metaphysics (and inherited from it, although on a critical mode, by Kant).
} 


\section{Aoristo)))))}

International Journal of Phenomenology, Hermeneutics and Metaphysics

while presented with any intra-worldly entity. Consciousness does even «explode» toward the world ([1939]): this explosion will become desiring production flowing all along the edge of the world as its moving and propelling limit. Deleuze and Guattari are here both a) reworking (through Bergsonian and Nietzschean means) Heidegger's idea that the world is the - moulding, shapening - horizon of any entity, its transcendental condition for coming to being; and b) taking advantage of Sartre's own Bergsonism in order to stretch the phenomenological (Husserl's and eventually Sartre's) notion of consciousness up; namely, up to make it focus into the world inasmuch as it has become itself the moving limit of its own production.

A network of interpretive lines can here be helpfully drawn: Husserl's notion of transcendental consciousness is indeed the root of Heidegger's world as the transcendental condition and horizon of appearing - it was so even before Sartre made it «explode» toward the world. On the other hand, both Sartre's Bergsonism and Fink's reading of Nietzsche as a transcendental philosopher (his eternal return being understood as quite a horizontal appearing of entitities) do together encourage to turn that liminal-worldly consciousness into a no less productive than exploding becoming - such as desire can be.

Desire, throughout the Anti-Oedipus, is the drive leading the production of the world - of no less than the world, far more than any item in it. Its objects are always partial, indeed, but this is just the way for the world to take place from one of them to the other. The world is as fragmented in partial objects as one ${ }^{6}$, a limit to be pushed forward at each item of any productive series of entities. Thereby, desire is immanent to such a world in the way (not of a part, but rather) of its moving horizon - moving because becoming, productive. Desire is as few a part of it as Sartre's consciousness was: its transcendence consisted just in its integral excursion into its objects: this is a sort of immanence to them. To be sure, not to any of them in particular, but indeed to a field for them to take place in and for consciousness to explode toward. Now such a field is just what the world is. Sartre's intentional transcendence of consciousness was an immanence to their vanishing line (a vanishing line, Fluchtlinie) into a world, whereby consciousness is transcendental, related to the appearing of its objects instead of being ("ontically") one of them, just because it relates to an entire world, over and above any of them, part of it. A world to explode toward prepares one to be produced by desire. According to the panoply of concepts newly created by Deleuze and Guattari, desire is steadily pushing forth its production, thereby taking place at the limit of its product. Once consciousness has turned into desire ${ }^{7}$, prompting production up to the brim is to draw the edge of the world.

So liminal is the world in respect to the entities in it as transcendental consciousness is suitable for letting us to understand it as being produced. The desire Deleuze and Guattari talk about in Anti-Oedipus is of course something displayed by

\footnotetext{
${ }^{6}$ Which matches the Being as univocal, cf. Badiou (1997).

${ }^{7}$ Sartre does not take himself this step; however, cf. Sartre (1938).
}

For a metaphysics out of joint: Deleuze, Heidegger... 


\section{Aoristo)))))}

International Journal of Phenomenology, Hermeneutics and Metaphysics

a concept precisely in the sense to be found in What Is Philosophy? ${ }^{8}$. It would be beside the point, therefore, to ask for a justification in the vein of a theory suitable for verification or falsification (even less in terms of an analysis of given notions) for such a way of conceiving of the world, entities and desire producing them.

Desire is then immanent to the world as its becoming and propelling horizon. It is because of this involvement in the world - because of an involvement precisely of this kind, which is not the one pertaining to an intra-worldly entity - that desire is not representative. It is the specific mode of inclusion of desire in the world that promotes its productivity to the status of an alternative à part entière to representation: desire is no external observer nor any part of the world, item in it, but rather a way for it to take place, a production of its entities that is liminal because it is constantly striving to go beyond any former product, any single object of desire it may have been directed to. This is why desire is a liminal consciousness, immanent rather to the world itself than to any item in it; and is thereby itself no intra- worldly entity. Producing turns out to be as transcendental and 'anontic' as Sartre's consciousness was. The desiring production takes place at the limit of the world, constantly in an escape that shifts away from any result to bring about itself as a production; and thereby a world, beyond any single entity Producing is producing something whatsoever, and thereby a world (in the same vein the mystical statement "something exists" equates to "a world exists"). At each step, in any single product (entity), it is in fact the world itself that takes place and produces itself; which is just what happens with Sartre's consciousness: while being completely open to its objects, without any reality of its own, it does just because of that transcend all of them to take place at their limit, as the appearing of any of them whatsoever. The only place it could take was in the world as such; the same happens when its «explosion» has become production.

Desire is no less cosmic than productive. Its production is the one of the world, by the world - rather than by a psyche as an entity deemed to represent. Desire is no attribute of an intra-worldly entity nor does it fulfill any representational task which would be to represent, in turn, intra-worldly entities (this is rather what in Deleuze - Guattari [1991] is given the name of "opinion"). There is a tie between mentalism as to desire (understood as an attribute of a psyche) and the representational notion of it, according to which the desiring psyche represents its objects - so to put in place the theatrical representation of a scene (desired just as is being played). In facts, psyche (if any; whenever any happens to be installed) is indeed representational - only, desire is not psychic.

\footnotetext{
${ }^{8}$ See mainly Chapter I.
} 


\section{Aoristo)))))}

International Journal of Phenomenology, Hermeneutics and Metaphysics

\section{GENERAL METAPHYSICS AND TRANSCENDENTAL PHILOSOPHY}

When producing replaces representing, does not only the shell of psyche break so to open itself to the world; moreover, does also the shell of special metaphysics break into the general metaphysics, to the question of the Being as such. Of course, conceiving of Being as production of entities is not mandatory, by itself, in order to have access to Being as such; and though, it is highly advisable, because it prevents from sliding into an ('ontic') conception of it hinging on entity. Which very easily happens, on the contrary, within the model of representation.

To conceive of Being as production is a way to understand Being in its difference from entity, which is a liminal-worldly difference, one between the world as a limit by which entities are conceived of as such (as being, in their Being) and those very entities sans plus. What the model of production specifically affords is a new, version of the very ontological difference. Being produced by 'difference and repetition' is, for entities, a sort of brand of their difference with their Being. This difference shoves constantly the entities to their limit, promoting thereby the prosecution of their series. The liminal-worldly difference with their Being performs in producing them by differentiation from one to another as steps in one series. Each repeats and differentiate itself from the former ones; this productive difference is ontological because by shoving each entity beyond its place in a series, it draws that horizon line that the world is. By a production by difference, Being happens.

If desire is productive by such a serial forwarding of the worldly limit, then the 'cosmology' of the desiring production is not merely a section of special metaphysics - not even one upsetting the very architecture of the latter by breaking through psychology. It does also, and most of all, break the shell of special metaphysics toward general metaphysics, within which it now moves as in its own element: for, if Being is world, cosmology merges with, or perhaps absorbs, ontology. Out of any architectural joints.

And even this is not all. Cosmology makes up, at the same time, an open gate for metaphysics onto transcendental philosophy. Not only does cosmology tend to expand into general metaphysics; provided Being is (as well the world as) the «virtual» - which is sense and event - it turns out that the very inquiry into Being fulfils its own transcendental investigation. Nothing less than this is at stake in Deleuze's theoretical works: metaphysics as such breaks into - or is broken through by - transcendental philosophy.

Here a step back is needed. Deleuze's masterpieces written few before he met Félix Guattari, namely [1968] and [1969], make up a link between Deleuze's former studies on Nietzsche [1962] and Bergson [1966] and his first book written together with Guattari. In the Anti-Oedipus an interplay is at work between Nietzsche's and Bergson's approaches to the cosmic becoming that owes much to Deleuze's own theoretical works from 1968-69.

It would be interesting to compare Deleuze's decade 1962-1972 with the

For a metaphysics out of joint: Deleuze, Heídegger... 


\section{Aoristo)))))}

International Journal of Phenomenology, Hermeneutics and Metaphysics

Heideggerian reading of Nietzsche proposed by Eugen Fink in his [1960]a, for the latter warrants for a link between the comprehension of the world as an horizon for the appearing of entities (far more Heideggerian a reading than the one suggested by Heidegger himself!) and the comprehension of Being as difference and repetition that Deleuze himself develops just from Nietzsche (read through Bergson).

Notice that Deleuze quotes Fink [1960]a in his [1968]; however, it is by drawing on his own theoretical elaboration that we can fully understand how A) his Bergsonian Nietzsche can play a performance within special metaphysics in AntiOedipus, namely in opening the psyche to the world; and B) the role played by that conception of the cosmic becoming in redefining the relationship between special and general metaphysics (see[1968]); as well as between metaphysics at all and transcendental philosophy (see [1969] and Deleuze- Guattari [1991]).

\subsection{TOWARD GENERAL METAPHYSICS}

To understand Being is to understand entity as such, i.e. as entity, in its being. A (classically known) way in which such an understanding happens to be grasped is when one notices for the first time (or as if for the first time) that something exists at all - and thereby that a world does. Through the leak of something an entire world passes through. A world, no matter how manifold - indeed it does not matter at all, it only matters that a world is given.

Heidegger indicates two radically different manners - that he traces back to Leibniz and Silesius, respectively - to elaborate philosophically such an experience of (the) existence (of the world) as such: by distributing the very event of the world inside the world itself, onto entities, by means of foundational links between entity and entity; or else by recognizing the foundationless event of the world at each occurrence of an happening whatsoever: each something repeats the unnoticed happening of the world. Wittgenstein, on the other hand, correlates the event of the world to the transcendental - liminal, mystical - subjectivity: the metaphysical subject is in fact transcendental. As empty of contents of its own, as straightforwardly open to the entire content of the world as Sartre's consciousness was. In both Sartre and Wittgenstein, consciousness is liminally immanent to the world as such. This turns the very problematic of special metaphysics into one pertaining to transcendental philosophy.

In Deleuze such a transition passes through general metaphysics, inasmuch as it implies a new, specific comprehension of Being in its difference form entities. In [1968], Being is understood as difference producing entities by putting them in a series whose varying items do together configure a world, one becoming by displacement (from inside) of its own limit. The liminal comprehension of the series, i.e. the comprehension of the world as such, is here attained by pushing forward the 


\section{Aoristo)))))}

International Journal of Phenomenology, Hermeneutics and Metaphysics

series themselves, by a displacement of their limit lead from this very limit, at each production of a new - repeating and varying - item.

\subsection{TOWARD TRANSCENDENTAL PHILOSOPHY}

By this new comprehension of Being, general metaphysics delivers a special metaphysic where psychology is deprived, or freed, form psyche and cosmology is open to chaosmos. Deleuze's transcendental philosophy inherits such results (see Preface to his [1969]). He then draws from the Stoical theory of event (tynkhánon; symbebekós) and sense (lektón) much more than suggestions in order to elaborate a notion of event, one capable to match the comprehension of Being attained in the book of the former year, where difference and repetition displayed the event of the world itself.

While such an event was mystical in Heidegger and Wittgenstein, it will be paradoxical in Deleuze: the leading thread to the Stoics is provided by Lewis Carroll... On the other hand, he explicitly declares that the Stoical lektón traces forth to Husserl's noema, while the transcendental field investigated by the phenomenologist (see Sartre [1935]) is one of pure, impassible events. These are virtual causally inefficacious, and though belong to the realm of what is realized (they are more than merely possible). Such a field is in fact the one of Husserl's transcendental subjectivity, once any anthropomorphic reading of it has been discarded (here Jan Patočka is of some help). Transcendental subjectivity is as impersonal as liminal-worldly. That was the root of both Heidegger's investigation of the worldly appearing (Being) of entities and of Sartre's explosions toward the world. So we have come back to our starting point; and though, something has changed: Deleuze's own contribution has brought something new. At each repetition, difference is at work: «the circle is not round».

\section{CONCLUSIONS}

One issue remains open: is it really necessary to erase transcendental subjectivity in order to get rid of anthropomorphism? This is what Deleuze himself maintains (see [1969]). He did so after he shook general and, thence, special metaphysics - at the expenses, in particular, of psychology. One can wonder, however, whether this result really need to be transferred from metaphysics to transcendental philosophy. Once special metaphysics has got free of any personalist format, must transcendental subjectivity still be kept in suspicion? Once general metaphysics has understood Being as a becoming of entities by differentiation within a series, a desiring subjectivity is likely to be immanent to such entities understood as such, in their being, as a world.

For a metaphysics out of joint: Deleuze, Heidegger... 


\section{Aoristo())))}

International Journal of Phenomenology, Hermeneutics and Metaphysics

\section{REFERENCES}

BADIOU, A. Deleuze. La clameur de l'être. Paris: Pluriel, 1997. . La conception de la différence chez Bergson. In: Etudes bergsoniennes, 1956, n.4.

DELEUZE, G. Différence et répétition. Paris: PUF, 1968. . Le bergsonisme. Paris: PUF, 1966. . Logique du sens. Paris: Minuit, 1969. . Nietzsche et la philosophie. Paris: PUF, 1962.

DELEUZE, G.; GUATTARI, F. L'Anti-CEdipe. Capitalisme et schizophrénie. Paris: Minuit, 1972. Qu'est-ce que la philosophie?, Paris: Minuit, 1991.

FINK, E. Das Spiel als Weltsymbol. W. Kohlhammer Verlag: Stuttgart, 1960. . Nietzsche Philosophie. W. Kohlhammer Verlag: Stuttgart, $1960 \mathrm{~b}$.

HEIDEGGER, M. Der Satz vom Grund. Pfullingen: Neske, 1957 . Einführung in die Metaphysik. Tübingen: Max Niemeyer, 1966 . Holzwege. Frankfurt am Main. Vittorio Klostermann, 1950. Sein und Zeit. Tübingen: Max Niemeyer, 1927. . Wegmarken. Frankfurt am Main. Vittorio Klostermann, 1967.

PATOČKA, Jan. Pour une phénoménologie asubjetive. In: Philosophie, phénoménologie, politique. Grenoble: Millón, 1992

RYLE, Gilbert. Sein und Zeit by Martin Heidegger. In: Mind, XXVIII 1929 [1949] . The Concept of Mind. Oxford: Oxford University Press, 1949

SARTRE, Jean-Paul. Esquisse pour une théorie des émotions. Paris: Hermann, 1938. . La transcendance de l'ego. Paris: Vrin, 1935.

. Une idée fondamentale de Husserl: I'intentionnalité. In: Situations I. Paris : Gallimard, 1939.

SINI, Carlo. I segni dell'anima. Roma-Bari: Laterza, 1989. . Immagini di verità. Milano: Spirali, 1985.

WITTGENSTEIN, Ludwig Tractatus logico-philosophicus ([1921)Frankfurt am Main: Suhrkamp 2003.

Submitted: April 2, 2020

Accepted: May 2, 2020

Maurizio Candiotto 